\title{
Translating Terms and Concepts in the Texts of Translation Studies
}

\author{
Esra Birkan Baydan \\ Marmara University, Translation and Interpreting Department \\ Istanbul, Turkey
}

Received: 13-12-2015

Accepted: 10-01-2016

Published: 01-04-2016

doi:10.7575/aiac.ijclts.v.4n.2p.18

URL: http://dx.doi.org/10.7575/aiac.ijclts.v.4n.2p.18

\begin{abstract}
This paper intends to explore challenges in translating terms and concepts of the social sciences within the frame of scholarly texts of translation studies translated into Turkish. Conceptual problems in the translation of scholarly texts in translation studies arise both from the "interdisciplinary" and "independent" nature of the field. Given the interdisciplinary nature of translation studies, key concepts of the influential movements of thought from adjacent fields pose challenges for the translator. Furthermore, terms which specifically belong to the field of translation studies require the translator to be familiar with the literature of the field in both source and target languages. Immanuel Wallerstein's suggestions for translating concepts of the social sciences are evaluated within this context with certain reservations. The translator of the scholarly texts of translation studies encounters challenges both with regard to "commonly shared" and "specific" concepts. Already existent Turkish translations of "common" concepts shared with the other disciplines are often diverse and varied, while some of the "specific" concepts of the field have not yet been translated. Both instances bring to the fore the translator's agency as the decision-maker who makes informed decisions among various alternatives. Examples ${ }^{i}$ of two Derridean concepts and two terms specific to the field of translation studies are provided to illustrate the problem-solving and decision-making process of the translator.
\end{abstract}

Keywords: Concept translation, Derridaen concepts, common concepts, specific concepts, translator's agency

\section{Introduction}

Translation Studies is now often considered an interdiscipline closely related to other disciplines such as linguistics, literary theory, historiography, psychoanalysis, philosophy, sociology and cultural studies; which often give rise to "turns" in translation studies. ${ }^{\text {ii }}$ Wolf (2007) explains this as follows:

This results partly from the fact that its subject is by nature located in the contact zones "between cultures", and is therefore exposed to different constellations of contextualisation and structures of communication, but also from the make-up of the discipline itself. (p. 3)

As a result, translation scholars and researchers employ theoretical insights from various fields of study and use key concepts from postmodernism, poststructuralism, deconstruction, feminism, postcolonialism and other movements of thought. As influential movements of thought like poststructuralism or deconstruction had an impact not only on the field of translation studies but on other disciplines as well, we encounter poststructuralist or deconstructive terms and concepts in a wide range of fields. Wallerstein (1981) suggests that:

In order to translate a concept well, the translator must know a) the degree to which any concept is in fact shared (and by whom), both at the time of writing and at the time of translation, and b) the variations of sharing communities in each of the two languages. (p. 88)

Wallerstein (1981) derives from the fact that concepts are "shared references of meaning, shared summations of data or classifications of reality" (p. 88). Consequently, the translator needs to read widely in and around the subject in both languages to understand the concepts and browse through relevant translated texts to find the available solutions already offered for the concepts. Nevertheless, as most of the concepts and terms are not originally developed within the Turkish system but "imported" in Even-Zohar's terms (2002, p. 169) through translations and retranslations, there is no consensus as yet as to their Turkish equivalents. Susam-Sarajeva's (2002) iii list of terms and neologisms in the retranslations of Barthes's texts into Turkish constitutes a case in point. Even one of the most prevalent terms such as idéologie used by Barthes in his "Que-est ce que la critique?" (What is Criticism?) is translated in three different ways as düşünce (thought), ülkü (ideal) and ideoloji (ideology) as listed by Susam-Sarajeva in Appendix 5 of her PhD dissertation thesis.

Another point made by Wallerstein (1981) about concepts is that, they are not "universally shared and are quite often the subject of open and violent conflict" (p. 88). Wallerstein concludes that "the translator should also be able to infer the author's perception" (ibid.). Wallerstein's statement takes into account the author's perspective of the concept, i.e. the way in which the concept is interpreted and instrumentalized by the specific author. The author might even defy the concept by incorporating newly assigned meanings. This point is also brought up by Joshua M. Price in his "Translating Social Science" written in response to Wallerstein's essay. Price (2008) subscribes to the fact that "the concepts 
themselves are not fixed" and that "good social scientists do not so much traffic in concepts as seek their elaboration (p. 350). In this sense, the concept, as is used by the author, might differentiate from or even subvert its prevalent use. This requires on the part of the translator to analyze and interpret the concept both within the unity of the text and the corpus of the author's works. Sometimes however authors make use of concepts to draw links with other disciplines or to establish similarities. For instance, Hermans (2007) in his "Translation, Irritation and Resonance", presents "a view of translation as a social system" in Niklas Luhmann's sense (p. 57). Hermans uses the concept 'autopoiesis' to demonstrate the link between Luhmann's notion of 'self-reproducing' social systems and Chilean biologists Humberto Maturana and Francisco Varela's coinage of the term 'autopoiesis', which they introduced to define a self-reproducing and self-maintaining biological organism. In other words, Hermans uses 'autopoiesis' as a concept to mark a similar characteristic shared by all three systems in the fields of biology, sociology and translation studies. ${ }^{\text {iv }}$

In summary, given the interdisciplinary nature of translation studies, translation scholars navigate between various disciplines and incorporate ideas into translation theories. They weave ideas from movements of thought into an argument which discusses, for instance, the influence of anti-essentialist, poststructuralist, postmodern views on translation. Consequently, the translator of scholarly texts of translation studies encounters concepts from other disciplines, on one hand. On the other hand, given the independent nature of translation studies, there are certain concepts specifically developed within the field either by translation scholars or scholars from neighbouring disciplines to explain translational phenomena. James S. Holmes" "The Name and Nature of Translation Studies"v, first delivered as a conference paper in 1972, is considered to be the founding statement of translation studies as an independent discipline, which led to a proliferation of ideas, theories and concepts about translation. Some of these terms and concepts have already been translated into Turkish but some are still waiting to be translated. We find translated terms and concepts either in translated essays of the discipline or in glossaries of translation terms in Turkish. ${ }^{\text {vi }}$ To translate specific terms and concepts of the field, the translator needs to be familiar with the literature of translation studies in both source and target languages, as also emphasized by Wallerstein (1981): the translator must ideally be "familiar with the literature of the subfield over a long period of time, and preferably someone with a direct interest in the material under discussion in the text" (p. 89).

In all instances, the translator has to make choices either among already offered alternatives or in offering suitable alternatives in his/her native language depending on his/her prior knowledge of the field. As Pym (2003) explains in a nutshell, translation is "a process of generation and selection, a problem-solving process" (p. 489). Examples of the translations of two Derridaen concepts and two specific terms of translation studies are provided to demonstrate the translator's problem-solving and decision-making process.

\section{Translation Solutions for Derridaen Concepts in Turkish}

Derridaen concepts of 'deconstruction' and 'différence/différance' have been translated into Turkish in various ways. In what follows, there is an account of various translation solutions offered for these two terms in Turkish.

\subsection{Deconstruction}

Derrida (1985), in his "Letter to a Japanese Friend" written to his Japanese translator, Prof. Izutsu, mentions that he,

wished to translate and adapt to [his] own ends the Heideggerian word Destruktion or Abbau. Each signified in this context an operation bearing on the structure or traditional architecture of the fundamental concepts of ontology or of Western metaphysics. (p. 1)

Derrida's coinage of the term 'deconstruction' implies an operation performed in relation to a 'structure'. However, he did not want to use the term 'destruction' because it implied "an annihilation or a negative reduction" (Derrida, 1985, p. 1). For him, the connotations of the word 'destruction' were closer to Nietzschean 'demolition' than to the Heideggerian term. Derrida meant to imply an act of both constructing and deconstructing in the type of reading he suggested. Therefore, he was in search of a word which would imply not one or the other but both. He decided on the neologism deconstruction.

The ambiguity of the word arises from its both structuralist and antistructuralist connotations. According to Derrida (1985), "its fortune rests in part on this ambiguity" (p. 2). The word signifies "a certain attention to structures" (ibid). Derrida, however, coined this word to emphasize the "undoing, decomposing, and desedimenting of structures" and in this sense "to deconstruct" is also an "antistructural gesture" (ibid).

Rather than destroying, it was also necessary to understand how an "ensemble" was constituted and to reconstruct it to this end. However, the negative appearance was and remains much more difficult to efface than is suggested by the grammar of the word (de-), even though it can designate a genealogical restoration [remonter] rather than a demolition. (Derrida, 1985, p. 2)

Therefore the indeterminacy of the concept should be taken into account in its translation. The translator would be then in search of a Turkish equivalent related to 'structure', which will, at the same time however, preserve the ambiguity arising from the combination of the word 'construction' with the prefix (de-). Derrida (1985) makes one last remark related to the translation of this word at the end of his letter:

I do not believe that translation is a secondary and derived event in relation to an original language or text. And as "deconstruction" is a word, (...), that is essentially replaceable in a chain of substitution, then that can also be done from one language to another. (p. 5) 
Here, Derrida (1985) attracts our attention to context and suggests that the word acquires its value only within a certain context, "where it replaces and lets itself be determined by [...] other words" (p. 3). Therefore, the translation of this word into another language will certainly lead to another network of words, and to another chain of signifiers determining each other's meaning potential.

Some of the translations offered for Deconstruction are as follows:

Kurgusöküm [see for example, Karadağ (2004)]

Yapıçözüm [see for example, Ece (2004)]

Yapıbozum [see for example, Megill (2008), (T. Birkan, Trans.); Direk (2006)]

Yapısöküm [see for example Derrida (2011), (İ. Birkan, Trans.)]

Within the possibilities of Turkish language (as there are no prefixes in Turkish) this word is rendered as a combination of two words in the above alternatives. The first one is the combination of kurgu (mounting, fitting, assembling etc. but mostly used in the sense of fiction) and söküm (disassembly, dismantle). The other three compound words are combinations of yapı (structure) and, 1) çözüm (noun form of untie, detach, unravel, disentangle etc. but mostly used in the sense of solution); 2) bozum (noun form of undo, disrupt, violate, ruin etc.) and 3) söküm (disassembly, dismantle).

In my translation of Arrojo's $(1995,1998)$ works I preferred yapısöküm for the following reasons:

The first part of the compound word is yap which means 'structure' in Turkish and Derrida (1985) specifically mentions that the word "signifies a certain attention to structures" (p. 2). The second part of the compound word in Turkish needs to reflect the prefix (de-) which has two meanings in English (Oxford Advanced Learner's Encyclopedic Dictionary):

1. opposite or negative of: [as in] defrost, decentralization

2. removal of: [as in] defuse, derailment

Söküm (disassembly, dismantle) is derived from the verb sökmek in Turkish. One of the meanings of sökmek is to disassemble the parts of something constructed. Derrida (1985) stresses that the "mechanical" association of the word deconstruction that he found in the Littré was "very fortunate, and fortunately adapted to what [he] wanted at least to suggest" (p. 1) and he cites some of the entries from the Littré. One of them is: "To disassemble the parts of a whole. To deconstruct a machine to transport it elsewhere" (ibid). Hence, the word söküm appeares as the most pertinent solution because it has this "mechanical" association.

\subsection{Différence / Différance}

According to Bennington (1993), “[t]his is a witticism of Derrida's” (p. 70):

In French, the difference between "différence" and "différance" is only marked in writing, which thus takes a certain revenge on speech by obliging it to take its own written trace as its reference. (pp. 70-71)

The distinction between these two words cannot be heard in speech but can only be recognized in writing. With these two words which are pronounced the same (homophones), Derrida criticizes the conviction that the written word is a derivative of the spoken word.

Some of the solutions offered for the translation of Différence / Différance are as follows:

Farklılık / Différance [see for example Ece, 2004]

Ayırım / A(yır)tım [see for example Boyne (1998), (A.B. Karadağ, Trans.); Karadağ (2004)]

Fark / Différance [see for example Direk (2006)]

Ayrım/ Ayram [see for example Lucy (2012), (S. Gürses, Trans.)]

Différence is translated as farklılık (disparity, dissimilarity, diversity); ayırım (distinction), fark (difference) and ayrım (the act of distinguishing, distinctive feature of a person or object, difference). Différance has not been translated in two of the above examples. Quoting from Moran, Ece (2004) asserts that it is not possible to translate différance into any language because of the "meaning load it bears" (p. 138, my translation). Karadağ preserves the closeness of sound of the two words in her translation of ayırım and a(yır)tım although however the ' $\mathrm{t}$ ' sound which differentiates $a(y \mathrm{lr}) \mathrm{tım}$ from ayırm can also be heard in speech. By writing the syllable (yır) in parenthesis, however, writing is placed in a more privileged position than speech, because it is only in writing that this parenthesis can be seen. In addition, when the word a(yır)tım is read without the syllable in paranthesis, the remaining word atım, which is the noun form of atmak as in 'gelecek bir tarihe atmak (ertelemek)' (to postpone to a future date), can be associated with 'delay'. Gürses prefers to use ayram for différance because of its similarity of sound with ayrim. Ayram is not a meaningful word in Turkish, but a word which gains its meaning from its 'difference' from the word ayrum. In other words, ayram gets its identity in its difference from ayrim. Gürses explains his preference in detail in a supplementary entry added by the translator to his translation of $A$ Derrida Dictionary.

I translated différence / différance as ayrım / ayırım with the following concerns in mind:

My initial concern was to find two words whose difference cannot be heard in speech but can only be observed in writing. My second concern was related to the following: Différance designates "the delay or lateness that means that 
meaning is always anticipated or else reestablished after the event" (Bennington, 1993, pp. 71-72). The meaning is delayed because "every present element (which is thus never really elementary or present) is stretched or spread between a 'past' and a 'future"' (ibid). We might infer therefore that it refers to the process and to the result of the process at the same time.

There are two separate entries for ayrım and ayırım in TDK Türkçe Sözlük (Turkish Dictionary):

Ayrım: 1. Ayırmak işi, tefrik (The act of distinguishing); 2. Bir kimse veya nesnenin bir başkasıyla karıştırılmamasını sağlayan ayrllık; benzer şeyleri birbirinden ayıran özellik, başkalık, fark (Distinctive feature of a person or object, difference); 3. Alt bölüm (Sub category); 4. Cinsleri ve türleri birbirinden ayıran ana karakter, fark (Main characteristic distinguishing types from one another); 5. Ayrlma noktast (Point of separation)

Ayırım: (yapmak) Eşit davranışta bulunmamak, fark gözetmek (Treat unequally, to practice favoritism, discriminate)

Ayırım: (yaratmak) Farklılık çıkarmak, ikilik ortaya atmak (To cause duality, difference (of opinion)

The first one, ayrim, refers both to the process or act of distinction and it is the result of the process at the same time. In other words, ayrim refers both to distinguishing elements from each other and to the result of this distinction, while ayırım refers to a duality, a difference of opinion and discrimination.

\section{Translation Solutions for Specific Terms of Translation Studies in Turkish}

\subsection{Abusive Fidelity}

Abusive fidelity as a notion was first conceptualized by Philip Lewis and has influenced other translators and scholars such as Lawrence Venuti, Lori Chamberlain, Suzanne Jill Levine, Sharon Willis and Luise von Flotow (see Arrojo, 1995, p. 24). Abusive fidelity is a translation strategy inspired by such poststructuralist notions as "the concept of meaning as differential plurality" (see for example Venuti, 1992, p. 12). It is a translation strategy which "accepts and exhibits its authorial force" (Arrojo, 1995, p. 24). In other words, the translator is aware of his/her interference in the text and this view supposedly releases translation from its subordination to the foreign text. Quoting from Lewis, Arrojo (1995) explains the reason for the choice of this word as follows: "The productive difference consisting in that twist or skewing signaled by the prefix $a b$ that is attached to the dominant c(h)ord of use" (p. 24).

This explanation brings a different insight to the word 'abuse' and the adjective 'abusive' derived from it. It attracts our attention to the combination of the prefix (ab-) with the word 'use', whereby the adjective form of the verb acquires a new signification other than its conventional use.

Not finding any previous translations of this term I had to produce a solution in Turkish. The newly planned language of Turkish after the Language Reform of 1920s has eliminated Arabic and Persian grammatical features and borrowings. As a result, there are no words combined with prefixes in Turkish. The verb 'abuse' in Turkish means (Redhouse English-Turkish Dictionary):

\section{Kötüye kullanmak, suiistimal etmek (abuse)}

2. Zarar vermek, incitmek (damage, harm)

3. Sövüp saymak, küfür etmek, şerefini lekelemek, ırza tecavüz etmek (speak insultingly, dishonour, defame, bring disgrace or shame)

In English (Oxford Advanced Learner's Encyclopedic Dictionary):

1. To make bad or wrong use of sth.

2. Treat (sb.) badly; exploit

3. Speak insultingly to or about (sb.); attack in words

We understand from the context that the first meaning is implied. One of the Turkish words kötüye kullanmak offered in the dictionary for 'abuse' is modern Turkish, while the other one suiistimal etmek comes from Arabic. It was important to use a prefix+word combination to render the notion quoted above in translation. The modern Turkish equivalent of 'abuse' is not a prefix+word combination, whereas the word suiistimal borrowed from Arabic is a combination of the prefix sú-i (bad) with the word istimal (put to work, use). Hence, I translated 'abusive fidelity' as suiistimalci sadakat.

\subsection{System}

'System' in general and in other contexts is usually translated as sistem into Turkish. However, 'system' and its derivative 'systemic' are specific terms of translation studies because they are related to Even-Zohar's Polysystem Theory. Bengi-Öner (2001) suggests the use of dizge for 'system' and dizgesel for 'systemic' in her Çeviri Terimleri Sözlüğ̈̈ (Glossary of Translation Terms) in relation to 'polysystem', which is translated into Turkish as çoğuldizge. However one cannot translate any 'system' or any derivatives of 'system' as dizge into Turkish automatically. Other derivatives of system, such as 'systematic' and 'systematization', for instance, are not directly linked to the Polysystem Theory. Therefore, in order to distinguish 'systematic' from 'system' and 'systemic' of Polysystem Theory, Bengi-Öner (2001) suggests the use of sistemli in Turkish which derives from the commonly used word sistem (system) in Turkish. (pp. 45-46). I followed the same line of reasoning for 'systematization' in the translation of the following passage and preferred to use a word which derives from sistem (system) but not dizge (system) in Turkish.

The desire to formulate universal translation laws has been further stimulated by the promises of systematization and meaning control implied by the emergence of linguistics as the science of 
language turned into the grand theory that would shed a definite light on all language phenomena, particularly since the early 1960s. Thus, the work of Georges Mounin (1963), J. C. Catford (1965) and Eugene Nida (1964), among others, has been hailed by many as the groundbreaking first steps towards the realization of the ultimate hope of systematization. (Arrojo, 1998, p. 28)

This last example illustrates the importance of being familiar with the field as well as analyzing the text and its context. For instance the names Mounin, Catford and Nida mentioned in the above passage precede Even-Zohar and his Polysystem Theory. Therefore 'systematization' in this context needs to be differentiated from dizge in Turkish.

\section{Conclusion}

In conclusion, rules or guidelines for translating concepts, such as the ones suggested by Wallerstein, are helpful to a certain degree but each specific concept needs to be evaluated and accounted for in its specific context. Price (2008), for instance criticizes the "normative" nature of Wallerstein's rules (p. 350). There is a wide range of alternatives in each specific case of translating the concepts of the social sciences and the translator cannot be made into a mere "rulefollower" in Price's (2008) words.

The examples selected from my own experience of translating the texts of translation studies demonstrate that the translator's reasoning of the concepts guides their decisions. Translators either select among already existent solutions, as in the example of deconstruction, or generate new alternatives, as in the example of différence / différance if they are not satisfied or convinced with solutions offered by other translators.

Consequently, translator's agency as a decision-maker needs to be acknowledged given the fact that translators make decisions among alternative solutions based on their analyses of the text and context. It is my contention that what would be more useful than general guidelines for translating concepts is translators' commentary on their decisions, such as the one presented in this paper.

\section{References}

Arrojo, R. (1995). The death of the author and the limits of the translator's visibility. In M. Snell-Hornby, Z. Jettmarova \& K. Kaindl (Eds.), Translation as Intercultural Communication (21-32). Amsterdam and Philedelphia: John Benjamins.

Arrojo, R. (1998). The revision of the traditional gap between theory and practice and the empowerment of translation in modern times. The Translator, 4(1), 25-48.

Bengi-Öner, I. (2001). Çeviri Terimleri Sözlüğü. İstanbul: Sel Yayıncılık.

Berk, Ö. (2005). Kuramlar Işı̆̆ında Açıklamalı Çeviribilim Terimcesi. İstanbul: Multilingual.

Bennington, G. (1993). Différance. Jacques Derrida (70-84). Chicago and London: Chicago Press.

Boyne, R. (1998). Foucault ve Derrida'da Feminizm ve Ayırım. (A.B. Karadağ, Trans.). İstanbul: Sel Yayınc1lık.

Derrida, J. (1985). Letter to a Japanese friend. In Wood \& Bernasconi (Eds.), Derrida and Différance (1-5). Warwick: Parousia Press.

Derrida, J. (2011). Gramatoloji. (İ. Birkan, Trans.). Ankara: Bilgesu Yayıncılık.

Direk, Z. (2006). Derrida ve sorumluluk olarak Avrupa Fikri. Cogito, 47-48, special edition: Derrida: yaşamı yeniden düşünürken, 213-223.

Ece, A. (2004). Yapısalcılık sonrası yaklaşımlar ve çeviribilim. Litera, 16, 135-152.

Even-Zohar, I. (2002). The making of culture repertoire and the role of transfer. In S. Paker (Ed.). Translations: (Re)shaping of Literature and Culture (166-175). İstanbul: Boğaziçi University Press.

Hermans, T. (2007). Translation, irritation and resonance. In M. Wolf \& A. Fukari (Eds.), Constructing a Sociology of Translation (57-75). Amsterdam and Philadelphia: John Benjamins.

Holmes, J. S. (2000). The name and nature of translation studies. In L. Venuti (Ed.), The Translation Studies Reader (172-186). London and New York: Routledge.

Karadağ, A. B. (2004). Çeviri ve çevirmenin edebiyat ve kültür dizgesini şekillendirmedeki rolü. Varlık, 1155, 9-15.

Lucy, N. (2012). Derrida Sözlüğü. (S. Gürses, Trans.). Ankara: Bilgesu Yayıncılık.

Megill, A. (2008). Aşırılı̆̆ın Peygamberleri. (T. Birkan, Trans.). Ankara: Ayraç.

Price, J. M. (2008). Translating social science: good versus bad utopianism. Target, 20(2), 348-364.

Pym, A. (2003). Redefining translation competence in an electronic age. In defence of a minimalist approach. Meta, XLVIII, 4, 481-497.

Snell-Hornby, M. (2006). The Turns of Translation Studies. Amsterdam and Philadelphia: John Benjamins.

Susam-Sarajeva, Ş. (2002). Translation and Travelling Theory. PhD Thesis: University College London.

Venuti, L. (1992). Rethinking Translation: Discourse, Subjectivity, Ideology. London and New York: Routledge. 
Wallerstein, I. (1981). Concepts in the social sciences: problems of translation. In M. Gaddis Rose (Ed.), Translation Spectrum: Essays in Theory and Practice (88-98). Albany: State University of New York Press.

Wolf, M. (2007). Introduction: The Emergence of a Sociology of Translation. In M. Wolf \& A. Fukari (Eds.), Constructing a Sociology of Translation (1-36). Amsterdam and Philadelphia: John Benjamins.

\section{Notes}

${ }^{\mathrm{i}}$ Examples are selected from my unpublished translations (completed for MA and PhD projects) of Arrojo (1995), Arrojo (1998) and Hermans (2007).

ii See for example Snell-Hornby (2006).

iii Susam-Sarajeva's PhD Thesis (2002), displays diverse and varied translations of terms.

${ }^{\text {iv }}$ For this reason, Theo Hermans mentioned that he wished that this term be preserved in its Turkish translation in our email correspondence.

v See Holmes (2000).

vi See for example, Bengi-Öner (2001) Çeviri Terimleri Sözlüğü (Glossary of Translation Terms) and Berk (2005) Çeviribilim Terimcesi (An Annotated Translation Terminology in View of Theories). 